\title{
Rethinking the Encounter Between Law and Nature in the Anthropocene: From Biopolitical Sovereignty to Wonder
}

\author{
Vito De Lucia ${ }^{1}$
}

Accepted: 24 September 2020 / Published online: 22 October 2020

(c) The Author(s) 2020

\begin{abstract}
The rise of the idea of the Anthropocene is promoting multiple reflections on its meaning. As we consider entering this new geological epoch, we realize the pervasiveness of humankind's deconstruction and reconstruction of the Earth, in both geophysical and discursive terms. As the body of the Earth is marked and reshaped, so is its idea. From a hostile territory to be subjugated and exploited through sovereign commands, the Earth is now reframed as a vulnerable domain in need of protection. The mode of sovereignty, which has accompanied human and legal history and practice during modernity and its project of mastery, is no longer useful. Humanity's control of the Earth is being reimagined and reconfigured along biopolitical coordinates of thought and action. Biopolitics shifts the focus of power, changes its modalities of interventions, and rearticulates its legitimacy on the idea of taking responsibility for the Earth, for nature. A biopolitical re-orientation of law captures the fundamental aim of caring for nature, of fostering its vital possibilities and of enhancing its productive potential. Yet, biopolitics engulfs nature in its entirety under its framework of control, where protection and subjugation, vulnerability and productivity, life and death are constantly entangled in a reciprocal and inevitable relation of indistinguishability. Sovereignty becomes thus a key modality of biopolitical intervention, when nature is recalcitrant, wild, spontaneous, unpredictable, violent, dangerous. Biopolitics, thus, remains caught in an undecidable dilemma, where in order to protect the Earth, it must subjugate it; to save it, it must condemn it. In this respect, biopolitics remains utterly modern, or as argued by Roberto Esposito, modernity has always been biopolitical, insofar as modernity has emerged as a framework for the protection of life against life's own excesses. But how can we escape the biopolitical reframing and enframing of the Earth and its total subsumption under its matrix of control? How can we rethink the encounter between law and nature without remaining entangled in the aporetic dilemma of biopolitics? An aesthetics of wonder may offer a way.
\end{abstract}

Extended author information available on the last page of the article 
Keywords Anthropocene $\cdot$ Biopolitics $\cdot$ Critical legal theory $\cdot$ Natural law $\cdot$ Sovereignty

\section{Introduction}

The rise of the idea of the Anthropocene is simultaneously prompting multiple reflections on its meaning and increasing engagement with its implications for (critical) legal theory. The geological question is whether the Anthropocene should be treated as a new geological epoch. There are however several further questions, as the Anthropocene has quickly become a central conceptual framework whose utilization has 'rapidly escalated' in a multiplicity of scholarly disciplines (Lewis and Maslin 2015, p. 171). The Anthropocene raises new and crucial questions related to the identification of 'the non-negotiable planetary preconditions that humanity needs to respect in order to avoid the risk of deleterious or even catastrophic environmental change at continental to global scales' (Rockström et al. 2009, p. 2). While the suggested formal periodization sets the beginning of the Anthropocene in the middle of the twentieth century, it can be argued that there is significant overlap between modernity as both a historical period and as a cultural project and at least an important intensification of the effects of the Anthropocene. The key connection between the two is arguably represented by the rise of capitalism (De Sousa Santos 1995). ${ }^{1}$ The Anthropocene, however, also signals a paradox, insofar as the very modern categories that underpin it, are now in a state of crisis precisely because of their success (De Lucia 2017a). The Anthropocene then signals simultaneously a deep ecological crisis (UNEP 2012, p. 4), ${ }^{2}$ and a deep cultural crisis: as the Earth is marked and reshaped, so is its idea. This is perhaps the key effect of the emergence of the idea of the Anthropocene: the Earth is recognized as vulnerable to human agency. From a hostile and unknown domain to be subjugated and exploited through sovereign commands, the Earth is now reframed as a vulnerable domain in need of protection. The mode of sovereignty, which has accompanied human and legal history and practice during modernity and that has underpinned the modern project of mastery at least since Francis Bacon's comprehensive project, ${ }^{3}$ is no longer useful (Sargent and Bacon 1999).

The argument in this paper is that the emergence of the idea of the Earth as vulnerable is transforming, rather than displacing, the project of human control of the Earth, now being reimagined and reconfigured along biopolitical coordinates of thought and action. This is because biopolitics shifts the focus of power, changes its modalities of interventions, and rearticulates its legitimacy on the idea of taking

\footnotetext{
1 Specifically relevant for the 'interpenetration' of modernity and capitalism.

2 For example, the UN Environment Programme (UNEP) held that ' $[\mathrm{t}]$ he scale, spread and rate of change of global drivers are without precedent. Burgeoning populations and growing economies are pushing environmental systems to destabilizing limits'.

3 Indeed, Bacon articulated a very comprehensive and detailed project for extracting Earth's secret through science and technology. For comprehensive critiques of Bacon's project and on the mastery over nature approach, see e.g. Merchant (1990) and Leiss (1994).
} 
responsibility for the Earth, for nature. A biopolitical analysis of law captures its role and its operation in the context of the new and fundamental aim of caring for nature, of fostering its vital possibilities and of enhancing its productive potential. It addresses and changes the role and operation of law as it envelops Earth as a vulnerable body. Yet, biopolitics presents an irresolvable internal contradiction, an aporia, as Esposito calls it (Esposito 2008, p. 39). A biopolitical articulation of law engulfs nature in its entirety under an ambivalent framework of management and control, where protection and subjugation, vulnerability and productivity, life and death are constantly entangled in a reciprocal and inevitable relation of indistinguishability. It is in this oscillation, in this aporetic space between the two poles of this relation that sovereignty emerges again, in its intimate, perhaps fundamental character. Sovereignty re-emerges as a key modality of biopolitical intervention, when nature is recalcitrant, wild, spontaneous, unpredictable, violent or dangerous. Biopolitics, thus, and law as one of its theoretical and operational instruments, remains caught in an undecidable dilemma, where in order to protect the Earth, it must subjugate it; to save it, it must be able to tame it, dominate it, even kill it. In this respect, biopolitics remains utterly modern, or as argued by Roberto Esposito, modernity has always been biopolitical, insofar as modernity has emerged as a framework for the protection of life against life's own excesses (Esposito 2008). But how can we escape the biopolitical reframing of the Earth and its total subsumption under its fostering power? How can we break out from this aporetic situation, where positive turns continuously into negative, where a politics of life turns incessantly and inevitably into a politics of death? These questions have been grappled with by fundamental elaboration of biopolitics (Agamben 1998; Esposito 2008; Hardt and Negri 2011), yet answers elude us still (De Lucia 2019a). This paper will try and imagine a different trajectory for law through an aesthetics of wonder, and thus try to rethink the encounter of law and nature.

The paper is structured as follows. Section two outlines the role of the Anthropocene in the discursive transformation of the Earth from a store of resources to be extracted and exploited, to a vulnerable domain. Simultaneously, section two will discuss how this discursive transformation also affects the role of sovereignty as a mode of power and as a legal paradigm. Section three presents the new biopolitical framework of action aimed at protecting this vulnerable Earth and discusses briefly the new role of law in a biopolitical context. Section four illustrates the internal contradiction of biopolitics, and its intimate relation with sovereignty, which is re-activated every time it is necessary to further the goals of biopolitics. Section five tentatively presents a way to disarticulate the biopolitical aporia through an aesthetics of wonder. Section six outlines in some detail, yet still tentatively, ways to rethink the encounter between law and nature, anchoring wonder on a relational ontological basis. Section seven offers some conclusions, though a more fitting ending for the paper, given the tentative and provisional tone of sections five and six, would be to leave it non finite (Gilbert 2003). 


\section{The Anthropocene and the 'Vulnerable' Earth}

The rise of the idea of the Anthropocene is simultaneously prompting multiple reflections on its meaning (Zalasiewicz et al. 2019) and increasing engagement with its implications for (critical) legal theory (Matthews 2019). The geological question is whether the Anthropocene should be treated as a 'formal chrono-stratigraphic unit'. ${ }^{4}$ At the moment, the consensus within the working group on the Anthropocene established under the Subcommission on Quaternary Stratigraphy (SQS) holds that the Anthropocene is 'stratigraphically real' (Zalasiewicz et al. 2017, p. 55). There are, however, several further questions, as the Anthropocene has quickly become a discourse whose utilization has 'rapidly escalated' in a multiplicity of scholarly disciplines (Lewis and Maslin 2015, p. 171). Indeed, in a very short time, the Anthropocene has given rise to at least three dedicated academic journals. ${ }^{5}$ The Anthropocene raises new and crucial questions related to the identification of 'the non-negotiable planetary preconditions that humanity needs to respect in order to avoid the risk of deleterious or even catastrophic environmental change at continental to global scales' (Rockström et al. 2009, p. 2). While the formal periodization sets the beginning of the Anthropocene in the middle of the twentieth century, others have argued that there is significant overlap between modernity as both a historical period and as a cultural project and at least an important intensification of the effects of the Anthropocene (Zalasiewicz et al. 2017, p. 55). Indeed, while the geological community is focused on where to set the formal boundaries between the Holocene and the Anthropocene, ${ }^{6}$ critical humanities scholars - including critical legal scholars - focus perhaps more on the cultural and political implications of the Anthropocene, which has 'irrevocably disturbed' the key 'political imaginaries' of modernity (Matthews 2019, pp. 2-3), and on its material effects, on its incisions on the body of the Earth (Malm and Hornborg 2014; Grear 2015; Matthews 2019). ${ }^{7}$

As the body of the Earth is marked and reshaped, however, so is our conception of it. From a hostile territory to be subjugated and exploited through sovereign commands - an exploitation rationalized through philosophical and legal constructions - the Earth is now reframed as a vulnerable domain in need of protection (Fussel 2007, p. 156; Grear 2011; Ippolito and Sánchez 2015; Shindel 2016; Kotzé

\footnotetext{
${ }^{4}$ A question discussed and voted on by the working group on the Anthropocene established under the Subcommission on Quaternary Stratigraphy (SQS), which in turn is a constituent body of the International Commission on Stratigraphy (ICS), which in turn is the largest scientific organisation within the International Union of Geological Sciences.

5 Such as Anthropocene (http://www.journals.elsevier.com/anthropocene/); The Anthropocene Review (http://anr.sagepub.com/); and Elementa: Science of the Anthropocene (www.elementascience.org).

${ }^{6}$ For example, several different positions with regards to the beginning of the Anthropocene have been the subject of considerable debate during the second Anthropocene Working Group meeting (Edgeworth et al. 2016).

7 Although they do not remain immune from a definitional obsession, see e.g. Matthews (2019, pp. 2-3), which recalls some of the labels that have been associated with the Anthropocene and to its putative temporal or cultural scope: Capitalocene, Technocene, etc.
} 
2019). ${ }^{8}$ Indeed, the Anthropocene 'makes clear the vulnerability of the living order' (Kotzé 2019, p. 63). Reframing the Earth as vulnerable also provides a novel conceptual framework that, through the emerging ensemble of vulnerability theories, is used to map philosophical and legal problematics and to look for solutions (Grear 2011, p. 23; Brama and Grisólia 2012; Harris 2015; Kotzé 2019, p. 63). This theoretical approach is considered capable of embracing vulnerable beings both human and non-human, as it can offer a 'vision' aligned with the notion of 'Earth system vulnerability', that is the recognition that 'all human and non-human entities' but also the 'components and processes making up the entire Earth system' at every scale, 'are vulnerable' (Grear 2011; Kotzé 2019, p. 64). Indeed, the sum of all particular vulnerabilities - of humans, of non-human entities, of components and processes of the Earth system-makes up what has been also called 'planetary vulnerability' (Kotzé 2019, p. 70). Climate Change is perhaps the central reference with regards to planetary vulnerability, ${ }^{9}$ but other global ecological problems, such as global biodiversity loss or the significant degradation of oceanic environments and resources, as well as the very framework of planetary boundaries, help construct this new image of planetary vulnerability (Rockström et al. 2009; Cuomo 2011).

This reframing of the Earth as a vulnerable body, in turn, opens conceptual and theoretical space for rethinking and reimagining, among other things, law (Grear 2011; Kotzé 2019). As the human subject is reimagined as vulnerable in the context of the Anthropocene, something becomes evident: the very modern categories of knowledge and of action, including forms and modalities of operation of power that underpin the Anthropocene, faced with the socio-ecological consequences of their 'success', are in a state of crisis (De Lucia 2017a). The subject is suddenly simultaneously sovereign and vulnerable. The Anthropocene then signals simultaneously a deep ecological crisis and a deep cultural crisis. The mode of sovereignty, which has accompanied human and legal history and practice during modernity and has underpinned its project of mastery, appears no longer useful, nor suitable to face the problems raised by planetary vulnerability. Vulnerability is, obviously, a complex concept, whose theoretical sophistication, as well as internal tensions, cannot be done justice to here. ${ }^{10}$ What is relevant however, for the purposes of this paper, is its role in the discursive reframing of the Earth and by consequence, its role in the shift in the psychology and practices of power and law. If the Earth is vulnerable in fact, its body can be materially and visibly marked by human activity-and that is what

\footnotetext{
${ }^{8}$ According to Shindel, vulnerability emerges initially as a scientific concept in geography but has then spread across a multiplicity of disciplines. Fussel holds that as a legally relevant theoretical framework it is particularly associated with human rights studies. However, it has recently been used in the context of environmental legal studies with increasing frequency, in accordance with Kotzé, which uses the framework of vulnerability across both fields of studies. This widespread use indicates how vulnerability is utilized as a 'conceptual cluster' that facilitates 'integrative human-environment research' (Fussel 2007, p. 156).

9 Vulnerability (to climate change) is indeed one of the themes of the monumental reports carried out every five years by the Intergovernmental Panel on Climate Change (IPCC), in particular through its third working group (on impact, adaptation and vulnerability).

${ }^{10}$ For a critical exploration of vulnerability theory, its productive potential and its potential pitfalls see e.g. Fineman and Grear (2013).
} 
geological and stratigraphic analyses seem to be telling us. This also means that its resources are finite and exhaustible, a recognition that challenges some of the foundational concepts of law, premised on an imaginary of inexhaustibility. ${ }^{11}$ What then of the primary modality of operation of power, and of law, that of sovereignty? ${ }^{12}$

A necessarily cursory look at the genealogy of sovereignty will readily show how its conceptual core ${ }^{13}$ is constructed on the model of dominium as it emerged at the birth of modernity, in the debates first occasioned by the so-called dispute on poverty (Grossi 1972; Tierney 1997; Parisoli 2010); as it developed in the context of the Salamanca school (Grossi 1972); and as it further developed into modernity proper (Tuck 1998), albeit already disjointed in private appropriation and public sovereignty, by Hobbes and Locke (MacPherson 1962; Esposito 2008). This conceptual core reflects the relation between the public and private dimensions of a singular concept, whose relation, even if not exhausting either dimension in a complete mutual assimilation, presents a common underlying feature, particularly as regards the mechanics of subjugation of nature which are of interest for this paper. As observed in relation to the colonial appropriation of the Americas, in fact, 'absence of property signals absence of sovereignty' (Kuehls 1998, p. 43). This connection between dominium and sovereignty is indeed widely recognized, ${ }^{14}$ and it has been observed how 'sovereignty and property, as legal institutions, follow the same logic' (Mattei 2013; Lee 2012, p. 81; Urueña 2006; Grotius 1625). This conceptual core also relates to what is usually identified as the fundamental flaw of the current paradigm: anthropocentrism (Grear 2011; Curry 2011; Grear 2015; Philippopoulos-Mihalopoulos 2015; De Lucia 2017b). The core of this sovereign paradigm is premised on the centrality of the 'invulnerable' subject (Grear 2010; Fineman and Grear 2013; Kotzé 2019, p. 79), and on a framework of conceptual mastery and material domination over nature (Cannavò 2019) ${ }^{15}$ which organizes the extraction and exploitation of natural resources according to a well ordained project underpinned by an appropriate legal framework (Merchant 1990; Sargent and Bacon 1999). Through sovereignty, the body of Earth has been materially and legally appropriated, has been distributed, and has been wounded. However, this sovereign mode of power, with its anthropocentric, extractive outlook, is no longer functional

\footnotetext{
11 Concepts such as sovereignty, res nullius, the freedom of the seas (and especially fisheries), just to mention some illustriously illustrative examples.

12 I will conflate within the political and legal philosophical concept of sovereignty both the private law dimension of private appropriation and the public law dimension of State sovereignty.

13 Here I am mostly concerned with the underlying idea of a sovereign subject that obtains prior to the distinction between public and private.

14 As Lee observed, there are at least two 'different historical pathways' through which theories of sovereignty developed, one grounded on the public legal notion of imperium, and the other drawing from private 'proprietary concepts of dominium'. Grotius also articulated this intimate connection by distinguishing dominium vulgaris, pertaining to the private property of the individual, from dominium eminens pertaining to the sovereign.

15 The two aspects being intimately linked, as suggested by Cannavò: 'Invulnerability [...] involves oppression and domination [as it] presupposes an ideology of mind/body dualism that justifies control and mastery over the body, other animals, and nature'.
} 
in the Anthropocene. It has rather become 'counterproductive' (Illich 1976). ${ }^{16}$ Law must reflect this new situation by taking 'anthropocenic responsibility' (Cloutier de Repentigny 2020, p. 180) for the well-being of the vulnerable planet. As increasingly recognized and urged, in fact, 'to ensure responsible human geological agency, law must be used strategically to destabilise the dominant paradigm and reform it in something that recognises our responsibility towards the oceans and the biosphere' (ibid, pp. 180, 181).

\section{After Sovereignty: The Biopolitics of Earth-Care}

As the Earth is reconfigured and re-imagined discursively as a vulnerable body, power and law must no longer focus, nor can they build their legitimacy, on appropriation and extraction. They must focus on care.

In order to accommodate the need to transform the operations of law, from a modality of exploitation to one of care, sovereign power thus morphs into biopower, and more specifically biopolitics. Biopolitics offers in this respect an answer, as it shifts the focus of power, changes its modalities of interventions, and rearticulates its legitimacy on the idea of taking responsibility for the Earth, for nature.

Biopolitics is one of two modes of operation of a new biological form of power (biopower) that seizes life under its purview (Foucault 1978, 2004). Biopower reflects a shift in discursive and operative emphasis. While sovereign power entails the right to let live which is ultimately exercised through the power to kill (or, rather, through its restraint), biopower is a power to 'make live and let die' (Foucault 1978, p. 144). Unlike sovereign power, biopower qualifies, measures, appraises and hierarchizes, with the ultimate aim of fostering life. This is achieved at two levels. At the level of the individual body, through disciplinary interventions; and at the level of populations, through interventions aimed at controlling life as a set of biological processes. The goal of biopolitics is thus to foster life, insofar as it can be regularized and its processes predicted and optimized.

With particular respect to the environment, nature is no longer simply an object of sovereign exploitation, but becomes subjected to a series of positive interventions that aim at its care, at fostering and optimizing its processes, and at the same time at the enhancement of its productive forces. Biopolitics enfolds nature in its logic in two distinct but complementary ways: firstly, as a set of processes central to human well-being, to the extent that human populations are affected in multiple ways by the environment they live in and by natural processes; secondly, as the immediate focus of concern. From this second perspective, biopolitics aims at the protection, regularization and optimization of nature itself (De Lucia 2019a).

Furthermore, and in line with Foucault's insight into the co-implicated relation between power and forms of knowledge, the expansion of biopolitical regimes to

\footnotetext{
16 The concept of counterproductivity indicates that every process, concept or institution, once passed a certain threshold, ceases to be useful and 'paradoxically takes away from society those things [it] was designed to provide' (Illich 1976, p. 79).
} 
the natural environment is historically contingent on the development of a number of scientific disciplines such as biology and ecology, on key conservation concepts such as biodiversity or sustainable development, as well as on a number of technologies and techniques that allow the continuous monitoring of ecosystem processes (De Lucia 2017a). Ecology in particular plays a crucial part, as it "provided the political technology for new forms of regulatory intervention in the management of the population and resources' (Rutherford 2000, p. 4).

Environmental law, from this perspective, becomes a crucial juncture where knowledge and power intersect and coalesce into a regulatory framework aimed precisely at classifying, protecting, regularizing and optimizing nature, particularly through the double goal of conservation and sustainable use of biological diversity (De Lucia 2017b, 2019a). Power governs no longer through sovereign command, but through technical norms and scientific regimes of knowledge (though always through law!). ${ }^{17}$ Power, through biopolitics, becomes equivalent with Earth-care.

\section{Care and Subjugation: Biopolitical Sovereignty}

Yet, to achieve its purposes, biopolitics must engulf nature in its entirety under a conceptual and regulatory framework where care and subjugation, vulnerability and productivity, life and death are constantly entangled in a reciprocal and inevitable relation. Sovereignty thus returns inevitably as a key modality of biopolitical intervention, when nature is recalcitrant, wild, spontaneous, unpredictable, violent or dangerous. Biopolitics remains caught in an undecidable dilemma, where in order to care for and protect the Earth, it must subjugate it, thus determining simultaneously the displacement of sovereignty and its eternal return, in a continuous oscillation between a positive biopolitics and a negative thanatopolitics (that is, a politics of death) (Agamben 1998; Esposito 2008). This oscillatory, aporetic entanglement can be made immediately visible through two examples: ecosystem monitoring programs and the regulation of invasive alien species. With regards to ecosystem monitoring programs, for power to care proactively for the Earth through biopolitical interventions, it must first know. To know, and to keep this knowledge up to date, it must enfold each ecosystem, each ecological and biological process with extensive, penetrating and comprehensive assessment, monitoring and mapping programs.

These are indeed key tactics and methods of the relevant sciences such as conservation, biology and ecology. For example, the global biodiversity census proposed by famous conservation biologist Edward Wilson is a tactic that can be understood

\footnotetext{
17 This refers to the problematic equivalence between sovereign power and law that Foucault, in the view of some legal scholarship, makes in his work (for example Hunt 1992; Hunt and Wickham 1994; Wickham 2006). My argument by contrast is that this equivalence, which would mean that Foucault suggests that law 'supposedly disappears as both a practice and as a strategy of power and government as soon as the power over life emphasizes life's enhancement and optimization rather than its destruction' (De Lucia 2019a, p. 156), is largely based on a misunderstanding of Foucault's view on law. I have dealt at some length with this question elsewhere (De Lucia 2019a, especially chapter 8, p. 155ff.), so I will refer the reader to that work.
} 
biopolitically as a form of Foucauldian 'panopticism' (Foucault 1977) aimed at subsuming life/nature under a comprehensive 'modality of intervention' (Rutherford 2000, p. 140). Through its processes of 'identification, collection of specimens, and subsequent research', the global biodiversity census aims at 'neatly packaging' nonhuman nature into a set of designations which, in turn, facilitate both 'conservation and commodification' (Youatt 2008). This panopticist program of biopolitical surveillance is operationalized through the intersection of knowledge and power, of science and law, whose collaborative effort gives rise and shape to an ecological regime of truth enacted precisely through such intense and comprehensive monitoring programs-including the International Biological Program, ${ }^{18}$ the Global Census of Marine Life ${ }^{19}$ and the Global Taxonomy Initiative (GTI) ${ }^{20}$ From the biopolitical perspective embodied in such tactics and practices, "nonhumans are [ultimately] regulated and rationalised in matrices of knowledge and science, through which they are readied as productive resources for capitalism and mined as repositories of genetic information' (Youatt 2008, p. 394). These programs reflect the key biopolitical goal of 'planetary management' enacted through the establishment of surveillance mechanisms aimed at monitoring 'the vital signs of the planet' so as to 'aid humans in protecting its health' and care for planetary vulnerability (WCED 1987, para 56; De Lucia 2015). ${ }^{21}$

With regards to the regulation of invasive alien species, this oscillation is a central operational logic, given that in the same gesture life is protected and destroyed, fostered and killed, as the conservation of biodiversity must be ensured through the eradication of invasive alien species which are, literally, killed (for example via snipers or through poisoned pellets) (De Lucia 2018). This is precisely a biopolitical command which not only classifies 'life into species and populations', as part of its taxonomic efforts, but also decides 'who shall live and who shall die, what life-forms will be promoted and which will be terminated' (Biermann and Mansfield 2014, p. 261; see also Braverman 2018).

This illustrates vividly how biopolitics is fully intertwined with sovereign power. Its interventions, enacted through legal regulation, create a seamless matrix of care and control that effectively rests on a biopolitical sovereignty. This in turn offers a concrete example of the continuity between sovereignty and biopolitics that makes perhaps more explicit what has been described as a 'hidden point of intersection' (Agamben 1998, p. 11), or as a 'secret and essential' relation that signals

\footnotetext{
${ }^{18}$ Which is aimed at 'understanding the biological basis of productivity and human welfare' according to Rutherford.

19 'A 10-year international effort undertaken to assess the diversity (how many different kinds), distribution (where they live), and abundance (how many) of marine life [that] produced the most comprehensive inventory of known marine life ever compiled and cataloged' http://www.coml.org/about-census.

${ }^{20}$ Which is aimed at removing the so-called 'taxonomic impediment', that is, the lack of taxonomic knowledge, allegedly a key to the conservation of biological diversity, https://www.cbd.int/gti/default. shtml.

${ }^{21}$ This panopticism also illustrates what Philippopoulos-Mihalopoulos calls the 'tyranny of the centre', a tyranny which is equally operative in anthropocentric and ecocentric approaches to environmental law (Philippopoulos-Mihalopoulos 2015, p. 28).
} 
a fundamental 'logic of copresence' between the two (Esposito 2008, pp. 39-40). In this respect, biopolitics remains utterly modern, or as argued by Roberto Esposito, modernity has always been biopolitical, insofar as modernity has emerged as a framework for the protection of life against life's own excesses (Esposito 2008).

\section{Disarticulating the Biopolitical Aporia Through Wonder}

As the Earth is reframed as a vulnerable body in the Anthropocene, power shifts focus, modalities of interventions and goals, in order to reconstruct its legitimacy (challenged in the Anthropocene where all modern political certainties have been 'irrevocably disturbed') and to remain productive (Matthews 2019, p. 3). From a sovereign mode that appropriates and exploits the Earth and its resources, law, through biopolitics, must enter into a protective mode, caring for vulnerable bodies, fostering their capacity, enhancing their productivity. Yet biopolitics remains inevitably underpinned by an epistemology of mastery and often needs, to be operationalized, the sovereign command. Sovereignty in fact, while diminished or even dormant in a legal framework that focuses on the biopolitical notions of conservation and sustainability (De Lucia 2017a), rather than on exploitation, stands ready to be re-activated when a forceful intervention is needed to discipline recalcitrant nature. This continuous risk of transformation from a biopolitics of care to a biopolitics of death, with all its attendant sovereign choices as to who can live and who must die, is the core dilemma of this biopolitical shift. Esposito speaks in this respect of a constitutive dilemma of biopolitics, a 'never-released tension', a 'lacerating effect' (Esposito 2008, p. 32) that accompanies it, as the two poles of its articulation-life and politics - are engaged in an inevitable and insoluble struggle. The effects of this struggle are that life is caught in what Agamben calls the 'zone of irreducible indistinction'; that is, a site where inclusion and exclusion, law and violence, life and death, the political form of life endowed with rights and the bare life which can be killed with impunity, are inextricably linked (Agamben 1998, p. 12). And it is here, in this zone of indistinction, that the protection and enhancement of life is continuously at risk of becoming, or perhaps always already is, the subjection and subjugation of life. It is here, in this zone of indistinction, that biopolitics and sovereignty find their most intimate connection.

How can we then escape this dilemma, this continuous transformation of a politics of life into a politics of death? How can we resist the biopolitical enframing of the vulnerable Earth? How can we resist the total subsumption of nature under a legal power that cares? How can we break out from the continuous biopolitical oscillations between care and subjugation? Is it possible to retain the positive inflection of biopolitics without the subjugating elements? Is encaring (that is, a single gesture that simultaneously cares and enframes) inevitable in a biopolitical regime?

One way is perhaps to recognize how the complexities of the Anthropocene elude 'the possibility of "solving" it' (Petersmann 2020). In this respect, biopolitics reflects precisely a non-negotiable entanglement of all life with death. It is not a problem that can be solved. However, the distribution of life and death, in all its complexity, can and should be problematized. Aesthetics may offer in this regard a 
way forward that remains attuned to such complexity. As Matthews has observed, in fact 'one of the greatest challenges that the Anthropocene thesis poses is an aesthetic one' (Matthews 2019, p. 3). The Anthropocene urges us to problematize how we sense the world around us, through what sensibilities (Petersmann 2020), and through what 'modes of perception' (Matthews 2019, p. 3). And here it is important to recover the broad semantic field of aesthetics (De Lucia 2016; Matthews 2019), which Matthews evokes, with a contrasting purpose, through the term aesthesis (Matthews 2019). This reactivated semantic field speaks of intellect and discernment as well as, importantly, of awareness and perception-a sort of "non-cognitive porosity' of the body, in the words of Anna Grear (De Lucia 2016). Sensing, in this broad meaning, thus becomes a crucial dimension for thinking differently about/ beyond the Anthropocene.

Sensing, perception, awareness: these all require something to sense, to perceive, to be aware of; they require a relation. Although the mode of relation that is required to disarticulate the biopolitical aporia is of a special kind. Here Tolkien, as mediated and elaborated by Patrick Curry, may be of help, through the concept of wonder. Tolkien distinguishes between two ways of entertaining a relationship with the world: magic and wonder (or, better, enchantment, though I prefer the term wonder as it does not resonate with a Weberian discourse). Magic entails the wilful exercise of power with the purpose of domination; it enacts a singular relational stance to the world; and is firmly anchored in a centre from which, and for whose benefit, the world can be controlled and manipulated (Curry 2012, p. 76). Tolkien describes magic as a 'technique' that 'produces, or pretends to produce, an alteration in the [world]' in order to 'dominat[e] things and wills' (Tolkien 2001, p. 53). Magic coerces. Magic is thus aligned with the modern epistemology of mastery and facilities its continuous and relentless transformation into domination (Leiss 1994). In this respect, it is easy to see the continuity between magic and science, as observed by Curry:

As a matter of philosophical, practical and historical fact, these two [magic and science] share extensive common ground-much more than what divides them. The principal goal of both is to engineer changes in the [...] world, and both try to amass knowledge in order to predict and control that world; both adhere to the idea of laws of nature which can be manipulated for human gain. That those laws are spiritual or occult in the case of magic and material in the case of science is a point of ultimately secondary importance. (Curry 1999, p. 402)

Further, as Curry still emphasizes, 'science never rejected the occult - literally what is hidden', but rather 'redefined it' (Curry 2019, p. 21). Magic is thus central to the project of modernity; is central to the exploitation of nature and the epistemology of mastery. However, magic remains also crucial once nature has been discursively reframed as vulnerable, for the biopolitical project of Earth-care, though it now underpins and enables an epistemology of care. Biopolitics in fact must know before it can regulate and ultimately care, and as such, it needs to engulf the planet, as we have seen, in its panopticist frameworks of surveillance and control. It needs to envelop the world with magic. And law is utterly dependent on this knowledge for 
its regulatory web to be laid on the world for its protection (De Lucia 2017b, 2018, 2019a). And this is precisely one of the mechanics through which biopolitics and sovereignty jointly operate, and through which the positive inflection of biopolitics inevitably becomes a subjugating framework of control: in order to care you need to know, and to know you need to engulf, surveil, predict. In this way, care is continuously transformed into subjugation, and only through subjugation is it possible to care.

However, just as much as biopolitics is inevitably caught in the continuous process of transformation of care into subjugation, an inner tension exists between the mode of knowing we have described as magic_epistemology_and what can be described, by contrast, as the mode of knowing of wonder-which is rather an aesthetics, in the sense explained just above. Wonder, ${ }^{22}$ as a mode of encountering the world, is premised on relational diversity. Indeed, wonder requires a gap between each party of the relationship, over which they can meet (Curry 2019, p. 13). This encounter, in turn, "creates a "third thing", something new in the world: a metaphorical you-and-me, or a this-but-also-that' (Curry 2019, p. 13). This is crucial: wonder eschews equally hyper-separation and total unity, it is a mobile, tentative and oscillating relation that does not settle once and for all, but negotiates the tension aesthetically, through what Curry, following Keats, calls 'negative capability' (ibid, p. 16). Wonder thus requires the capability of 'being in uncertainties, mysteries, doubts' (ibid, p. 16). ${ }^{23}$ Additionally, and this is a crucial aspect of the relational world of wonder, there is no centre in wonder, or, rather, the centre exists between the 'two or more parties, and thus cannot simply be occupied by any one of them' (Curry 2019, p. 15). As Curry observes, when it comes to wonder, 'no one is in charge' (ibid). Wonder, unlike magic, is a way to enter into a relationship in a non-coercive fashion (Curry 2012, p. 76). Wonder, thus, is 'distinct from will' (ibid). Finally, the parties of the wonder-full relation need not be humans-wonder puts into relation all sort of beings, things, places and even ideas (Curry 2019, p. 24), thanks to their diversity.

Wonder, through its centre-less relational modality, through its way of knowing which is an entering-into-relation, may help chart a novel trajectory that does not take sides but remains, firmly, in the middle (as urged by Philippopoulos-Mihalopoulos 2011), ${ }^{24}$ navigates on the cusp, on the edge of the threshold, balancing without falling, yet without certainty. But what does this mean for law? How does this wonder-full, as it were, relational aesthetics help rethink the encounter between law and nature? My argument, which will be articulated in the next section, is that thinking through wonder may help chart a novel trajectory for the classical tradition of natural law. Through wonder, once again though differently, law is in the nature of

\footnotetext{
${ }^{22}$ In much of the work of Tolkien and Curry, which inspires to a significant extent this section at least in terms of the conceptual apparatus, wonder is a mode of relation that underpins enchantment. I will use wonder to encompass both.

23 This resonates strongly with Philippopoulos-Mihalopoulos' 'epistemologies of doubt', in which he problematizes every system of 'knowledge based on an a priori constructed centre of discourse' (Philippopoulos-Mihalopoulos 2015, p. 28, emphasis in the original).

24 Taking sides and the idea of the middle - as opposed to the centre-are themes discussed often by Philippopoulos-Mihalopoulos.
} 
things (Villey 1969), that is, in the middle of this relational world. Here it is however important to note the crucial distinction between the classical framework of natural law, which I am connecting with and re-activating, and the modern, rationalist school of natural law. ${ }^{25}$ In the classical school of natural law, which finds its roots in the pragmatic legal consciousness of ancient Rome, and further links with Aristotle's notion of particular justice (Villey 2003, p. 78ff), there is no eternal, fixed law proceeding from the will of god or from the dictates of reason. Indeed, natural law is one of a multiplicity of co-existing legal orders. ${ }^{26}$ This natural law returns to law as an art (rather than a technique) and does not have a centre-there is no privileged subject, will, or god. As a relation, it is a measure, and is tensive, historically situated, alive, uncertain, negotiable and contestable. It is, indeed, somewhat 'wild and unbiddable' (Curry 2019, p. 15), ${ }^{27}$ like wonder, and requires, like classical natural law, a prudential and flexible approach to contingency (Villey 2001, p. 160). It is a law that, perhaps best denoted as jus, is sensed.

\section{Rethinking the Encounter Between Law and Nature}

\section{An Ontology 'for' Wonder}

Before rethinking the encounter between law and nature, however, it is necessary to revisit an ontological question, upon which an aesthetics of wonder can be made theoretically operational. This revisiting is in part prompted by the 'end of the backdrop ontology' signalled by the Anthropocene which underpins modern political and legal thought (Matthews 2019, p. 3). In part, though it is also prompted by the fact that '[t]he word "nature" [and thus the meaning of natural] is equivocal' (Villey 2001, p. 156). Yet, the 'method of natural law' prompts us to 'observe the world' (ibid.), as law is not deduced logically, nor demonstrated scientifically, but observed; it is not fixed, but mobile, situated and historical; it is not discovered through reason, but through sensing it - that is, it is not epistemological, but aesthetic.

So, to approach nature - and thus later law, in their encounter-I shall draw on the work of Norwegian philosopher Sein Anders Noer Lie and his 'relational dispositionalism' (Noer Lie 2016). The starting point for Noer Lie's work is the attempt to rethink the concept of naturalness. The current philosophical debate on nature and on naturalness, observes Noer Lie, is stuck (ibid.). He wishes however to re-open it, with the view of enabling an environmental practice that simultaneously respects the role of human subject as a natural agent (including scientific practice and technological developments) and allows the consideration of

\footnotetext{
25 For in depth discussions see Villey (2003, 2008) and Passerin d'Entrèves (2009).

26 In the Roman view, jus naturale is that particular legal order 'quod natura omnia animalia docuit'; that is, that which nature teaches to all animals, and coexists with jus gentium and jus civile (Ulpianus, D. 1.1.1.3).

27 Curry describes thus enchantment, rather than wonder, but as explained, I utilize wonder to also encompass what Curry and Tolkien describe as enchantment.
} 
certain practices as preferable (i.e. more natural) than others, without, however, recourse to contestable ethical bases. This approach arguably allows, as Foucault would say, eschewing 'moral righteousness' in favour of a 'politics of projects and strategies' (Koopman 2013, p. 142). Precisely that situated, prudential, flexible approach that underpins the method of classical natural law-what perhaps here we can call, slightly tongue-in-cheek, wonder-full natural law.

Noer Lie targets four 'ontological opponents' to the idea of naturalness: necessitation; contingency; reductionism and constructivism (Noer Lie 2016, p. 57). Ontologies of pure necessitation (i.e. fully deterministic) do not allow any flexibility and consequently would not even pose the question of whether a certain course of action may be preferable to another. Ontologies of contingency consider nature to be a collection of independent entities only 'contingently connected' to one another (ibid., p. 19). This perspective conceives of the entire world as 'loose and separate', with the consequence that things have no intrinsic purpose or nature (ibid., p. 61). In turn, any connection among things is as contingent as any other, so that any combination of connections is equally possible and valid. The outcome is then that it is impossible to consider any of the combinations intrinsically more natural, and hence preferable, than any other. Ontologies of reduction (e.g. essentialism) postulate that a thing possesses certain essential properties that allow it to express the same qualities 'under any condition'. The essence of things, from this perspective, is 'the particular constitution which every thing has within itself, without any relation to any thing without it' (Locke 1690 in Noer Lie 2016, p. 53). Ontologies of construction (i.e. constructivism), finally, privilege epistemological inquiries over ontological ones on the basis that we cannot say anything about reality without inquiring first into the conditions under which our knowledge of reality is produced. This however, suggests Noer Lie, is an unrecognized ontological commitment insofar as it claims that reality "must in each and every case be accessed as something "in itself", that is 'independently from everything else' (Noer Lie 2016, p. 22). In particular, with respect to the latter ontological opponent, Noer Lie suggests an 'ontological reorientation' whereby the very question of access is mooted, as, in a Heideggerian sense, we are always already in the world (ibid., p. 24). There is thus no escaping-nor any need to escape - a context in which everything is, as it were, connected to much-if not everything-else (Commoner 1972, p. 16). Things and beings are then such as they are, not because of their independence from everything else, but because of their 'relation to other beings' (Noer Lie 2016, p. 24). It is the relations they entertain with other things that allow some of their available dispositions, or propensities, to become manifest precisely through relations.

Importantly, Noer Lie's conception of naturalness, contains a crucial historical dimension. While recognizing that things have a set of potentialities or propertiesthat is, dispositions - indicating a set of possible states whose manifestation depends on their relational context, he also underlines how such dispositions are simultaneously historically given. In other words, things are such as they are because of both their relational history (which forms the basis of the present set of dispositions that a thing possesses) and of the current relational context in which they exist (which elicits the manifestation of certain dispositions, and not others). 
But what are, really, these dispositions? Dispositions, suggests Noer Lie, 'are properties that describe what some given entity is able to do and to forbear' (ibid., p. 87). The ability to do is key here, as it indicates a shift from a passivist to an active ontology. Things - all things, and not only living entities!-from this perspective have agency, in the sense that they are able to do a number of things (behave in a certain way) based on the dispositions they possess. In this dispositional account then, agency indicates a 'certain readiness that an entity has to perform specific kinds of behaviour under specific kinds of conditions' (ibid., p. 88). This readiness, and these abilities, are in turn historically developed and activated through relations. ${ }^{28}$ A stone breaking if hit with a hammer is the result of the stone doing the breaking, due to its disposition to break becoming manifest when hit with a hammer (the hitting being the particular 'relational partner', as Noer Lie calls it, of the stone), and not the result of its passive and deterministic reaction to the agency of the human hitting it with the hammer. The stone agentially breaks (as opposed to being broken) when it enters into a relation with the hammer and its force. More generally, a dispositional ontology is premised on the idea that 'to understand what something $i s$, is to understand what it does and can do' (ibid., p. 89).

This ontology of dispositions does a few 'tricks' that enable an epistemology of wonder. It finds agency everywhere. It makes agency, and ontological actualization, contingent at once on history and on relations. It removes a centre, and instaurates precisely that gap; that difference between the parties to a relation as the focus of attention.

\section{Dispositions, Wonder and Law}

The method of natural law is based on observation, and if relational dispositionalism enables an aesthetics of wonder not as a true way of knowing, but as a better-and indeed, more natural, in the sense explained above-way of knowing, law is to be found precisely in the encounter of wonder-full relations. Law is again about boni et equi, as the category of truth loses relevance, and that of goodness becomes central. Law is again an art, and not a deductive science, nor a sovereign command. The natural law of wonder does not point us, in fact, to true law. It points us to good law, albeit in a limited temporal and spatial context. Yet good law is not based on an ethical choice-'moral righteousness' - but on an ontological horizon that is accessible through the relations and the aesthetics of wonder. But what does it mean that truth is no longer a relevant category, while good is? A further explanation about the dispositional ontology may help.

It is important to note at this point that naturalness must be understood in the sense of indicating the sum of historically determined manifested dispositions, which, as Noer Lie underlines, leave ample room for discovering and rendering manifest many other dispositions that things and entities possess (Noer Lie 2016). The 'actual history of the universe' does not, in other words, exhaust the range of

\footnotetext{
28 And, importantly, while manifestations are contingent, dispositions are real regardless of whether they manifest or not.
} 
the 'physically possible'; yet the physically possible, while not unnatural strictly speaking, is untested in the world-that is, it is not historically co-evolved-and does often carry consequences that cannot be (easily or immediately) absorbed by the natural dispositions manifested in the world (an example of such consequences is toxic pollution or biotechnology) (ibid., p. 160). In order to make this distinction clearer, Noer Lie uses two terms that he describes as 'technical' in order to de-activate the opaque meaning-making associated with the use of the controversial, ambiguous and intuitive term naturalness (ibid.). Thus, Noer Lie deploys the concepts of possible-N and possible-I (ibid., p. 159). The first refers to the actual history of the universe. Things are the way they are because of their multiply entangled relational histories. Possible-N is, simply, the world (Cosi 1990). Possible-I, on the other hand, refers to human activity, experimentation and technology. Possible-I indicates then not the true essence of the world, as scientific realism would have it, but the discovery of other dispositions, and possible worlds; ones no less true than the natural world, yet no more true either. Moreover, and importantly, possible-I worlds have not historically co-evolved through dispositional partnering in the world and, hence, while we may come to know how they work under laboratory or otherwise controlled conditions, we do not yet know the unfathomable risks they may pose if and when intersecting with the (possible-N) world. ${ }^{29}$

A further explanation of dispositions (and manifestations) is perhaps useful, and I will quote at length Noer Lie:

Imagine a stone $1[$ a]ying on the ground. What kind of dispositions does this stone have[?] Well, a wide and in principle, endless range. The reason for that is that the dispositions of the stone depend on its relational partners. But, in reality very few of them are manifested. The reason for that is that the stone has been a part [of an historically specific assemblage of dispositional partners]. However, humans can provide other partners that are not given for free by the course of the natural history of the world. It can make the stone do a multiple set of things. It can even bring the stone into the laborat[or]y and widen the range of manifestations further [than those that are historically given]. (Noer Lie, personal communication)

Put differently, the world is made up of actual manifestations, each of which depends on the complex whole and how the different parts enter into relations with one another. Each, however, possess further dispositions whose manifestation may be elicited by, say, scientific experiments. Both are true, but only some are natural, in the restricted, historical and contextual sense indicated here. Moreover, often 'human-induced' dispositions can only manifest in certain conditions that do not exist in the natural (in a dispositional sense) world and hence require the re-structuring of the world-with possibly catastrophic consequences.

These considerations lead to a difficult task for natural law, yet one that has a clear goal: discovering good law in the nature of things, that is, in the ontological history and relational composition of the world. Rethinking the encounter between

29 This logic clearly supports the wide implementation of the principle of precaution. 
law and nature in this way puts it on useful ontological foundations. The aesthetics of wonder, in turn, tells us that knowing does not happen from a centre, but in the middle of the world - in fact in the middle of a relation. Yet the aesthetic legality of wonder offers no fixed or predictable solution (Villey 2001, p. 158ff.). It only offers a method for discovering good law. The notion of 'good' however needs also to be unpacked. It is, emphatically, not a moral category. It is rather an aesthetic category grounded in a dispositional ontology. Good is what follows the natural propensity, disposition, inclination of things. Most activities (cutting meat, chopping woods, growing food, fishing, conserving forests) can be done in many ways, but there is often one (or a restricted range of) optimal way(s). There is however nothing which is optimal in and of itself. Optimality, like the good I am referring to in the context of the aesthetics of wonder, is relational. Optimality, Noer Lie suggests in this respect, exists 'due to the existence of [...] possible-N', that is, a world 'that is relationally and historically constituted' (Noer Lie, p. 167).

The good lies thus in a (set of) relation(s): in the gaps and the differences that a relation bridges but does not eliminate; in ways of knowing; and in ways of acting that reflect the (dispositional) naturalness of/in the world. Natural Law is thus natural in this sense. And it is in this sense, by sensing, as it were, that it appears again in the nature of things, in this novel manner, as naturalness 'belongs to the world' (Noer Lie 2016, p. 166). However, like classical natural law, this natural law does not intend to exhaust the space of the legal (Villey 2001, p. 161ff.), but is rather one of a plurality of legal order(ing)s; and it is not in an antagonistic, but rather complementary relation with positive law, although it articulates a different concept of law and a different method. This approach ultimately articulates a particular, sui generis legal sensibility informed by the aesthetics of wonder, which is especially relevant to rethink the encounter between law and nature. It is capable nevertheless to explicate some efficacy across legal orders (De Lucia 2019b). The principle of precaution (which enjoins us to avoid risks of serious or irreversible environmental harm if available scientific knowledge is uncertain or inconclusive), is perhaps the existing legal principle that most closely aligns with a 'wonder-full' natural law, although the detailed implications of the substantive and operative horizon of the principle of precaution, as significantly recalibrated through an aesthetics of wonder and a dispositional ontology, cannot be explored here. But a natural law constructed-or better, discovered - through an aesthetics of wonder would inevitably demand a radical reconsideration of most central (environmental) legal principles, as well as probably most environmental legal theories, as they are all premised on a centre (Philippopoulos-Mihalopoulos 2015; De Lucia 2019a). This exercise, however, will have to be carried out in a future continuation of this paper. Here I have merely attempted to test and combine these ideas and to lay (some of the) conceptual groundwork.

\section{Conclusions: Wonder, Law and the Commons}

In this paper I have developed a narrative that starts from the 'fact' of the onset of a new epoch-the Anthropocene. This epochal shift reflects the geological significance of humanity as it has inscribed its actions on the surfaces and depths of 
nature. The paper has then problematized the reframing of the Earth as a vulnerable body that was prompted by the Anthropocene-of which climate change is perhaps the central manifestation-for its biopolitical implications. I have then pointed to the inherent and inevitable paradox of what I have described as the biopolitics of Earth-care: while aiming at protecting nature, biopolitics in fact inevitably engulfs it in a comprehensive matrix of control. Law, in this context, is a crucial element of the biopolitical enframing of nature, continuously oscillating between care and subjugation, life and death etc. What then? The paper has tried in its second part, to disarticulate the biopolitical aporia by starting from the notion of wonder: wonder as a mode of rethinking the encounter of law and nature, and as an aesthetics, in its broad meaning of plural and relational modality of knowing. From the perspective of wonder, I have also tried to rescue the classic idea of natural law. Ways of knowing however-and classic natural law, as a method, is a way of knowing rather than of willing-are contingent on their ontological premises. The paper thus has presented an ontological framework that reflects and enables an aesthetics of wonder. The task is however just at the beginning and surely many questions and indecisions remain, and this paper has only endeavoured to chart an initial trajectory for rethinking the encounter of law and nature through the aesthetics of wonder.

Acknowledgements I wish to thank the anonymous reviewers as well as Daniel Matthews and Kathleen Birrell for their insightful comments; Svein Anders Noer Lie and Julia Gaunce for many conversations about dispositions, naturalness and wonder; and Mana Tugend for her assistance in preparing this paper.

Funding Open Access funding provided by UiT The Arctic University of Norway.

Open Access This article is licensed under a Creative Commons Attribution 4.0 International License, which permits use, sharing, adaptation, distribution and reproduction in any medium or format, as long as you give appropriate credit to the original author(s) and the source, provide a link to the Creative Commons licence, and indicate if changes were made. The images or other third party material in this article are included in the article's Creative Commons licence, unless indicated otherwise in a credit line to the material. If material is not included in the article's Creative Commons licence and your intended use is not permitted by statutory regulation or exceeds the permitted use, you will need to obtain permission directly from the copyright holder. To view a copy of this licence, visit http://creativecommons.org/licen ses/by/4.0/.

\section{References}

Agamben, Giorgio. 1998. Homo Sacer: Sovereign power and bare life. Stanford: Stanford University Press.

Biermann, Christine, and Becky Mansfield. 2014. Biodiversity, purity, and death: Conservation biology as biopolitics. Environment and Planning D: Society and Space 32(2): 257-273.

Brama, Glenda Morais Rocha, and Cesar Koppe Grisólia. 2012. Environmental bioethics: Strategy to face planetary vulnerability. Revista Bioética (Impr.) 20(1): 41-53.

Braverman, Irus. 2018. Coral whisperers. Scientists on the brink. Oakland: University of California Press.

Cannavò, Peter F. 2019. Vulnerability and non-domination: A republican perspective on natural limits. Critical Review of International Social and Political Philosophy. https://doi.org/10.1080/13698 230.2019.1698155.

Cloutier de Repentigny, Pierre. 2020. To the Anthropocene and beyond: The responsibility of law in decimating and protecting marine life. Transnational Legal Theory 11 (forthcoming).

Commoner, Barry. 1972. The closing circle, nature, man, and technology. New York: Bantam Books. 
Cosi, Giovanni. 1990. Tutela del mondo e normatività naturale. In Il Meritevole di Tutela, ed. Luigi Lombardi Vallauri. Giuffrè: Milano.

Cuomo, Chris. 2011. Climate change, vulnerability and responsibility. Hypatia 26(4): 690-714.

Curry, Patrick. 1999. Magic vs. enchantment. Journal of Contemporary Religion 14(3): 401-412.

Curry, Patrick. 2011. Ecological ethics: An introduction, 2nd ed. Cambridge: Polity Press.

Curry, Patrick. 2012. Enchantment and modernity. PAN: Philosophy, Activism, Nature 12: 76-89.

Curry, Patrick. 2019. Enchantment: Wonder in modern life. Edinburgh: Floris Books.

De Boaventura, Sousa Santos. 1995. Toward a new common sense. Law, science and politics in a paradigmatic transition. New York: Routledge.

De Lucia, Vito. 2015. Competing narratives and complex genealogies: The ecosystem approach in international environmental law. Journal of Environmental Law 27(1): 91-115.

De Lucia, Vito. 2016. Re-embodying law: Transversal ecology and the commons. In Contributions to law, philosophy and ecology exploring re-embodiments, ed. Ruth Thomas-Pellicer, Vito De Lucia, and Sian Sullivan, 161-191. New York: Routledge.

De Lucia, Vito. 2017a. Critical environmental law and the double register of the Anthropocene: A biopolitical reading. In Environmental law and governance for the Anthropocene, ed. Louis J. Kotzé, 97-116. Oxford: Hart Publishing.

De Lucia, Vito. 2017b. Beyond anthropocentrism and ecocentrism: A biopolitical reading of environmental law. Journal of Human Rights and the Environment 8(2): 181-202.

De Lucia, Vito. 2018. Bare nature. The biopolitical logic of the international regulation of invasive alien species. Journal of Environmental Law 31(1): 109-134.

De Lucia, Vito. 2019a. The ecosystem approach in international environmental law Genealogy and biopolitics. New York: Routledge.

De Lucia, Vito. 2019b. Ocean commons, law of the sea and rights for the sea. Canadian Journal of Law and Jurisprudence 32(1): 45-57.

Edgeworth, Matt, Colin Waters, Jan Zalasiewicz, and Simon Stoddart. 2016. Second anthropocene working group meeting (Conference Report). The European Archaeologist 47: 27-33.

Esposito, Roberto. 2008. Bíos: Biopolitics and philosophy. Minneapolis: University of Minnesota Press.

Fineman, Martha, and Anna Grear. 2013. Vulnerability: Reflections on a new ethical foundation for law and politics. Gender in Law, Culture, and Society. Farnham: Ashgate.

Foucault, Michel. 1977. Discipline and punish. New York: Pantheon.

Foucault, Michel. 1978. The history of sexuality. An introduction, vol. 1. New York: Pantheon Books.

Foucault, Michel. 2004. Society must be defended. Lectures at the Collège de France 1975-1976. London: Penguin Books.

Fussel, Hans-Martin. 2007. Vulnerability: A generally applicable conceptual framework for climate change research. Global Environmental Change 17(2): 155-167.

Gilbert, Creighton E. 2003. What is expressed in Michelangelo's 'Non-Finito'. Artibus et Historia 24(48): 57-64.

Grear, Anna. 2010. Redirecting human rights: Facing the challenge of corporate legal humanity. Hampshire: Palgrave Macmillan.

Grear, Anna. 2011. The vulnerable living order: Human rights and the environment in a critical and philosophical perspective. Journal of Human Rights 2(1): 23-44.

Grear, Anna. 2015. Deconstructing Anthropos: A critical legal reflection on 'Anthropocentric' law and Anthropocene 'humanity'. Law and Critique 26(3): 225-249.

Grossi, Paolo. 1972. La proprietà nel sistema privatistico della seconda scolastica. In La seconda scolastica nella formazione del pensiero giuridico moderno: Incontro di studi, Firenze 16-19 Ottobre 1972, Proceedings/ed. Paolo Grossi. Milano: Giuffré, 117-222.

Grotius, Hugo. 1913 [1625]. De Jure Belli Ac Pacis Libri Tres:In Quibus Jus Naturae \& Gentium, Item Juris Publici Praecipua Explicantur. Reproduction of the Edition of 1646, Carnegie Institution of Washington, Lib. I, Caput I, § VI.

Hardt, Michael, and Antonio Negri. 2011. Commonwealth. Cambridge: Belknap Press of Harvard University Press.

Harris, Angela P. 2015. Vulnerability and power in the age of the Anthropocene. Washington and Lee Journal of Energy, Climate and Environment 6(1): 98-161.

Hunt, Alan. 1992. Foucault's expulsion of law: Toward a retrieval. Law and Social Inquiry 17(1): 1-38.

Hunt, Alan, and G. Wickham. 1994. Foucault and law: Towards a sociology of law as governance. London: Pluto Press.

Illich, Ivan. 1976. Medical nemesis. The expropriation of health. New York: Pantheon Books. 
Ippolito, Francesca, and Sara Iglesias Sánchez. 2015. Protecting vulnerable groups: The European human rights framework. Oxford: Hart Publishing.

Koopman, Ian. 2013. Genealogy as critique. Foucault and the problems of modernity. Indiana University Press.

Kotzé, Louis. 2019. The Anthropocene, Earth system vulnerability and socio-ecological injustice in an age of human rights. Journal of Human Rights and the Environment 10(1): 62-85.

Kuehls, Thom. 1998. Between sovereignty and environment: An exploration of the discourse of government. In The greening of sovereignty in world politics, ed. Karen Liftin, 31-54. Cambridge: MIT Press.

Lee, Daniel. 2012. Sources of sovereignty: Roman imperium and dominium in civilian theories of sovereignty. Politica Antica 2(1): 79-94.

Leiss, William. 1994. The domination of nature. Montreal: McGill-Queens University Press.

Lewis, Simon L., and Mark A. Maslin. 2015. Defining the Anthropocene. Nature 519: 171-180.

Locke, John. 1690. An essay concerning human understanding. London: Three Bibles.

Macpherson, Crawford B. 1962. The political theory of possessive individualism: Hobbes to Locke. New York: Oxford University Press.

Malm, Andreas, and Alf Hornborg. 2014. The geology of mankind? A critique of the Anthropocene narrative. The Anthropocene Review 1(1): 62-69.

Mattei, Ugo. 2013. Beni comuni. Un manifesto. Bari Roma: Laterza.

Matthews, Daniel. 2019. Law and aesthetics in the Anthropocene: From the rights of nature to the aesthesis of obligations. Law, Culture and the Humanities. https://doi.org/10.1177/1743872119871830.

Merchant, Caroline. 1990. The death of nature. Women, ecology and the scientific revolution. San Francisco: Harper One.

Parisoli, Luca. 2010. L'Emersione del soggetto di diritto dalla Chanson de Roland alla teologia politica Franscescana. In Il soggetto e la sua identità. Mente e norma, medioevo e modernità, ed. Luca Parisoli, 71-94. Palermo: Officina di Studi Medievali.

Passerin d'Entrèves, Alessandro. 2009. Natural law: An introduction to legal philosophy. London: Transaction Publishers.

Petersmann, Marie-Catherine. 2020. 'Staying with the trouble' - Sensing climate change in the Anthropocene. Völkerrechtsblog (27 April). https://doi.org/10.17176/20200427-164632-0.

Philippopoulos-Mihalopoulos, Andreas. 2011. Towards a critical environmental law. In Law and ecology New environmental foundations, Chapter 2, ed. Andreas Philippopoulos-Mihalopoulos. New York: Routledge.

Philippopoulos-Mihalopoulos, Andreas. 2015. Epistemologies of doubt. In Research handbook in human rights and the environment, Chapter 3, ed. Anna Grear and Louis Kotzé. Cheltenham: Edward Elgar.

Rockström, Johan, Will Steffen, Kevin Noone, ... and Jonathan Foley. 2009. Planetary boundaries: Exploring the safe operating space for humanity, Ecology and Society 14(2): art. 32. Available at https://www. ecologyandsociety.org/vol14/iss2/art32/. Accessed 27 September 2020.

Rutherford, Paul. 2000. The problem of nature in contemporary social theory. Ph.D. Thesis, The Australian National University, Canberra.

Sargent, Rose-Mary, and Francis Bacon. 1999. Selected philosophical works. Indianapolis and Cambridge: Hackett Publishing Company Inc.

Shindell, Matthews. 2016. A vulnerable earth. Science History Institute (2 June). Distillations. https://www. sciencehistory.org/distillations/magazine/a-vulnerable-earth. Accessed 25 August 2020.

Svein, Noer Lie. 2016. Philosophy of nature. Rethinking naturalness. London: Routledge.

Tierney, Brian. 1997. The idea of natural right: Studies on natural rights, natural law and church law 11501625. Grand Rapids: William B. Eerdmans Publishing Company.

Tolkien, John R.R. 2001. Tree and leaf. London: Harper Collins.

Tuck, Richard. 1998. Natural rights theories: Their origin and development. Cambridge: Cambridge University Press.

Urueña, René. 2006. Sovereignty as property: Rediscovering the economic foundations of sovereignty in international law. International Law: Revista Colombiana de Derecho Internacional 8: 195-230.

Villey, Michel. 1969. Dikaion-Torah. In Seize Essais de Philosophie du Droit, ed. Michel Villey. Paris: Dalloz.

Villey, Michel. 2001. Epitome of classical natural law (Part II). Griffith Law Review 10(1): 153-178.

Villey, Michel. 2003. La Formation de la Pensèe Juridique Moderne. Paris: Presses Universitaires de France.

Villey, Michel. 2008. Le Droit et les Droits de l'Homme. Paris: Presses Universitaires de France.

Wickham, Gary. 2006. Foucault, law, and power: A reassessment. Journal of Law and Society 33(4): 596-614. 
World Commission on Environment and Development (hereinafter WCED). 1987. Our Common Future: Report of the World Commission on Environment and Development, 4 August (A/42/427).

Youatt, Rafi. 2008. Counting species: Biopower and the global biodiversity census. Environmental Values 17(3): 393-471.

Zalasiewicz, Jan, Colin N. Waters, Colin P. Summerhayes, Alexander P. Wolfe, et al. 2017. The Working Group on the Anthropocene: Summary of evidence and interim recommendations. Anthropocene 19: $55-60$.

Zalasiewicz, Jan, Colin N. Waters, Mark Williams, and Colin P. Summerhayes. 2019. The Anthropocene as a geological time unit: A guide to the scientific evidence and current debate. Cambridge: Cambridge University Press.

Publisher's Note Springer Nature remains neutral with regard to jurisdictional claims in published maps and institutional affiliations.

\section{Affiliations}

\section{Vito De Lucia ${ }^{1}$}

$\triangle$ Vito De Lucia

vito.delucia@uit.no

1 Norwegian Centre for the Law of the Sea, Faculty of Law, UiT The Arctic University of Norway, PO Box 6050 Langnes, 9037 Troms $\emptyset$, Norway 